Маријана Јелисавчић

Универзитет Новом Саду

Филозофски факултет

marijanamajche@gmail.com
821.163.41.09-31 Живковић 3. https://doi.org/10.18485/ai_most.2017.ch16

\title{
О МОСТУ У МОСТУ ЗОРАНА ЖИВКОВИЋА
}

Феномен моста у истоименом кратком роману Зорана Живковића посматра се кроз призму необичних догађаја и сусрета који су јунаке три кратке приче које чине роман, довели на мост. Ти сусрети нису синхронизовани, већ се надовезују један на други, стварајући међусобно нераскидиву везу, како предметима који се гомилају, тако и мостом који у вртлогу немогућих прича постаје, како се чини, locus delicti. Мост постаје привремено складиште за ствари којих се јунаци ослобађају пре него што се попну на камену ограду и закораче ка воденом простору који се не проблематизује као могућа смрт, већ наставак дана који можда неће бити необичан попут догађаја који су јунаке довели на мост.

Кључне речи: мост, мантил, ешарпа, патике.

Вероватно најпознатији мост у српској књижевности јесте вишеградска ћуприја, коју је пре више од пола столећа описао наш нобеловац Иво Андрић. Својој фасцинацији, месту „на коме је човек наишао на запреку и није застао пред њом“, осим што је дао носеће место и улогу главног лика у роману На Дрини ћуйрија, Андрић је посветио и једну од најбољих својих прича - Мосии на Жейи, као и кратки текст Мосӣови. Са друге стране, ове структуре које код Андрића не служе ничем што је тајно или зло, у свету књижевне фантастике (најчешће 
фолклорне), која корене вуче из традиционалне културе нашег народа, представљају хтонско место ${ }^{1}$. Уколико би се јунак овог вида књижевности у недоба нашао на мосту, походиле би га авети или би му се десило нешто необјашњиво. Најбоља илустрација овог навода јесте прича Ноћ на мостиу Милована Глишића, у којој је за излечење човека који је „награисао“ неопходно суочавање са бестијаријумом који у глуво доба обузима мост.

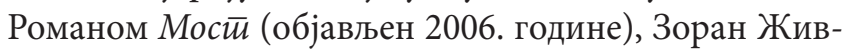
ковић, један од најпревођенијих и најплоднијих српских писаца, наставља традицију започету више од једне деценије раније: спаја неспојиво, игра се временом и простором, као и ликовима својих дела. Мост као један од најрепрезентативнијих хтонских простора традиционалне културе, наставља да као такав егзистира и у Живковићевом роману. Овде мост није место боравка нечисте силе у неком од својих класичних облика, већ је место на ком је видљив утицај више силе која јунаке прати од прве странице романа.

Композициони план Мостиа чине три наизглед неповезане приче, осим што је свака насловљена по једном

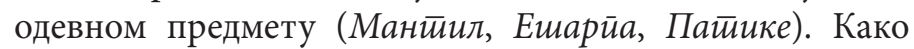
се приче развијају, тако се и корелације између њих усложњавају. Оно што на први поглед ствара атмосферу зачуђености јесу сусрети јунака са необичним особама. Човек из Манииила (који није именован, као ни простор којим се креће, те може имати улогу било кога), на улазу у зграду у којој живи среће себе. Госпођа Олга из приче „Ешарпа“ испред радње у којој је у току распродаја, види своју покојну сусетку Веру. Јунакиња приче „Патике“, госпођица Анита, на улици среће свог сина који ће се

Андрић ће то описати на једном месту у роману На Дрини ћуйрија кроз причу о Милану Гласничанину, који у глувој ноћи, на средини моста, коцкајући се са ђаволом, продаје душу Нечастивом. 
тек родити (она има само четрнаест година) ${ }^{2}$. Двојник, покојна сусетка и нерођени син ${ }^{3}$ имају битно обележје по коме их актери прича препознају: мантил, ешарпу и патике, одевне предмете какве имају и они сами. Ипак, интересантно је што су сва три предмета на неки начин фелерична, што им и даје ноту оригиналности: мантил има различите ревере (један заобљен, а други шиљат), на ешарпи се налазе две округле мрље налик на очи уснуле змије, а патике су разнобојне (једна је црна, а друга бела). Што се тиче боја, интересантна је и коса ${ }^{4}$ необичних посетилаца - двојник јунака из прве приче своју фарба у риђе, а госпођа Олга и госпођица Анита сусетку и сина затичу са таквим фризурама. „То је боја онога што је скривено (хтонска боја), унутрашње ватре [...] Код човека се риђа коса повезује са животињском природом и ђаволом: у средњем веку риђе људе сматрају сатанским створењима“. (Гарден и др. 2011, 484) Иако аутори Ларусовог

2 Према Срйском митиолошӣком речнику, мост је „омиљено место на коме се ђаволи одмарају и чекају жртве. Ту се ноћу привиђају разне приказе, па се зато мост сматра за нечисто место. Када сватови иду преко моста, девојка одива, прелазећи преко њега, баци новчић у воду, као жртву демону воде, и изговори: 'Пређох воду, не угазих, родих дете, не осетих!. (СМР 1970: 219) Иако у речнику ови наводи имају метафоричко значење, у Живковићевом Мосӣ $y$ могу фигурирати и дословно јер госпођица Анита није угазила у воду, а није ни осетила рођење детета. Такође, у овом одређењу могуће је ишчитати и симболику моста као хтонског места, и места на коме се врши свадбени обред, још један вид прелаза. „Такође је заступљена представа да још нерођена деца живе у изворима, бунарима, језерима или текућим водама“. (Ван Генеп 2005: 63)

3 Интересантно је што посетиоци могу образовати својеврсну породицу, јер се јављају као човек, жена и дете, као и људи који их прате - господин из прве приче, госпођа Олга и четрнаестогодишња Анита.

4 „Начин на који се поступа са косом врло често улази у категорију обреда прелаза“. (Ван Генеп 2005: 193) 
Малої речника симбола поистовећују риђу и наранџасту боју, Гербран и Шевалије (Речник симбола), праве велику разлику: наранџаста је боја равнотеже, на граници између жуте и црвене, а риђе „указује на паклени огањ који прождире, махнитање похоте, страственост жеље, топлоту из 'доњега света', све оно што уништава физичко и духовно биће“. (Гербран и Шевалије 2009: 784) Ово је један од начина на које би се необична дешавања могла повезати са упливом тајанствене силе у животе три појединца. Риђу косу имају и људи које јунаци срећу док се упињу да неупадљиво прате оне који су накратко прекинули мирне токове њихових живота, „чији су намерно замагљени тлоцрти осенчени сведеном, загаситом, неупадљивом гамом, која подсећа на фину сепију старинских фотографија. Фантастични простори приче и сна, насупрот томе, живобојни су, дивљи и неконвенционални. (Пешикан-Љуштановић 2016: 35-36)

У новинама, на страни о градској хроници, главни актер приче Маниичл прочитао је половичну (jер је део странице отцепио да би најправио рупу за шпијунирање свог двојника) вест о необичном самоубиству на неком мосту. На концу сваке од прича десиће се по један скок са моста који се не проблематизује као самоубиство, већ као скок у непознато, што је интересантно на више различитих нивоа.

Најпре, људи који својом појавом изазивају запрепашћење, подсећају на путнике из неке паралелне стварности, који су само свратили да би кроз низ необичних поступака испровоцирали оне који их примете. Ако ствари посматрамо на тај начин, скок са моста након којег се не чује пљусковита реакција воде, био би повратак у мултиверзум из којег су дошли. Странац који се појављује на једном простору, мора бити подвргнут и обрнутој церемонији испраћања, односно одвајања од тог света, чему, према Арнолду ван Генепу, одговарају 
„обреди опраштања: посете, последња размена дарова, заједничка трпеза, чаша вина при растанку, лепе жеље, праћење 'делом пута', некад чак и приношење жртви “. (Ван Генеп 2005: 43) Ван Генеп наводи да се путник при одласку мора опремити некаквим знаком распознавања, који би га аутоматски пропустио у одређено друштво. У том контексту, Живковићеви посетиоци испуњавају готово све обреде опраштања, нарочито праћење, размену дарова, и госпођицу Аниту као добровољну жртву, која се опрема одећом раније остављеном на мосту. Додела одеће поима се као крај иницијације. Брод би могао бити портал који промиче испод моста сваки пут када се путници појаве на средини камене површине са китњастим канделабрима, јер они долазе у различито време. О способностима необичних гостију да „испливају“ из невероватних ситуација сведоче догађаји у другом и трећем поглављу: госпођа Вера успева да нестане из базена у који је ускочила како би затвореницима свирала обоу, а син госпођице Аните нестаје из каде препуне ципела и појављује се на другом месту. Није случајност ни то што су оба нестанка повезана са површинама које се односе на воду.

Низ необичних догађаја који су се преплели тог дана, само потврђују да је реч о посетиоцима који не припадају свету обичних, регуларних збивања: двојник господина из приче Мантиил у цркви ће куглом гађати винске флаше, у четврти црвених фењера јести руже, на необичном рулету уложити дрангулије које је успут сакупљао, како би најзад са својим пратиоцем у корак отишао до моста, на коме ће оставити свој последњи залог - мантил различитих ревера. Госпођа Вера из поглавља Ещарйа радиће све оно што јој за живота није било својствено („Рекло би се да се људи промене после смрти“ (Живковић 2006: 53)) - надметати се са мајмуном у преједању, свирати обоу под водом, са повезом на очима бодежима гађати насумично одабране гледаоце (који ће са оштри- 
цама заривеним у тело устати као да се ништа није догодило), међу њима и своју сусетку Олгу (а број чијег седишта је 8 , који, када се посматра из друге перспективе твори знак за бесконачност), са којом ће у истом фијакеру кренути ка мосту, где ће заједничку реликвију, жуту ешарпу, положити преко тамнозеленог мантила и грациозно се винути у бездан. „Такође нико осим госпође Олге није био сведок догађаја који је убрзо уследио. Неки други очевидац можда би се зачудио одсуству пљуска у воду, али њој то уопште није изгледало необично. Изненадила би се, заправо, да је било шта чула“. (Живковић 2006: 82) Као што господин из прве приче одлучује да ће следећег дана купити нов мантил, једнаких ревера, тако и госпођа Олга себи обећава да ће се убудуће клонити распродаја. Међутим, госпођица Анита неће донети одлуку за будућност. Можда се управо њен случај односи на вест коју је господин из Мантиила у поцепаним новинама прочитао? А то, исто тако, може имати везе са тим што се предмет по којем она препознаје свог нерођеног сина, састоји из два дела, те га могу понети две особе.

у причи Пайике, момак којег госпођица Анита препознаје као свог будућег сина, чиме се између ова два лика остварује најприснија веза од свих „парова“ у роману, такође је учесник чудних збитија: он урања у каду са ципелама, прерушен у женско и увијен у тесто волшебно се појављује из пећнице у коју је убачен, са масним мушкарцем (који се појављује и у осталим причама) улази у игру погађања предмета, и последњи залог, разнобојне патике, ипак успева да сачува за мост, до којег се вози заједно са Анитом. Бицикл који је возио до средине моста, уз пљусак је пао у воду. Брод, који је замицао када су њихови претходници скакали, сада се зауставио, чекајући придошлице. „Био је раскошно осветљен, и искићен заставицама, пун ведре музике и људи који су им махали“. (Живковић 2006: 112) Људи 
на броду, претпостављеном порталу у другу стварност, могле би бити оне риђокосе прилике које су суделовале у несвакидашњим поступцима двојника, покојне сусетке и нерођеног сина. Одевена у мантил, ешарпу и једну патику, госпођица Анита скочила је заједно са својим сином. „Падали су брзо, али није било опасности. Када буду стигли до палубе, доскок у патикама биће лак попут перца“. (Живковић 2006: 112) Као стварном бићу, госпођици Анити биле су потребне ове реликвије ${ }^{5}$ како би на што бољи начин закорачила у иницијацију. „Противно усамљеничком, суицидалном читању окренутом смрти, Живковићеви јунаци скачу у двоје“. (Владушић 2007: 132-133) Временска раван је такође чудновата - сви јунаци долазе на мост у сумрак, а не срећу се на мосту. За сваког од њих, брод се наново појави. Због тога, вест коју чита господин из приче Манииил, може се односити на догађај који ће тек уследити, односно на једини скок стварне особе - госпођице Аните. Невероватност која би чинила окосницу новинског чланка, из те перспективе, био би Анитин нестанак.

Мост је у традиционалној култури представљен као веома битно место које означава обред прелаза:

Симболизам моста, као средства које омогућује прелазак с једне обале на другу, један је од најраширенијих симболизама. То је прелаз са земље на небо, из људског стања у надљудска стања, из пролазности у бесмртност, из чулног света у натчулни. (Гербран и Шевалије 2009: 586)

Мостови не служе само за повезивање, већ у симболичком смислу представљају и ситуацију прелажења у други облик постојања, који се може смисаоно савладати

5 „Пренос реликвија такође подразумева прелазни период од напуштања места на коме су претходно чуване до доласка на место где ће бити коначно смештене“ (Ван Генеп 2005: 215), тако да је читав пут јунака и њихових пратилаца обележен иницијацијски. 
само при тачно одређеним обредима преласка (rites de pasage). (Бидерман 2014: 287)

Такође, вода има велики значај када се посматра у традицијском кључу, као гранично место. Љиљана Пешикан-Љуштановић наводи да место и време са којим се вода повезује „гради хронотоп изразито амбивалентне природе у коме се додирују и међусобно опште простори

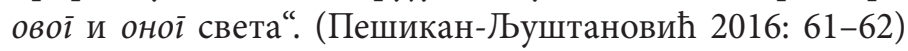
Пишући о иницијацијским церемонијалима у Елеусини, Арнолд ван Генеп ${ }^{6}$ описује довођење иницијаната до обале мора у коме види „обред одвајања од профаног света и претходног живота, прелиминарни обред“. (Ван Генеп 2005: 105) коме следује и купање као обред очишћења, што код Живковића изостаје.

Читава прича се склопила како би госпођица Анита уз свог сина, и са потребним магијским предметима, прешла у једну другачију стварност. Овог пута нема пљуска у воду, као ни при скоку претходних необичних људи, доскок који наслућује госпођица Анита, више ће наликовати слетању („попут перца“). Говорећи о физичком прелазу, ван Генеп истиче „пролаз кроз теснаце који подразумевају остављање разних предмета (камења, тканина, крзна и сл.), приношење жртви“ (Ван Генеп 2005: 27), јер се људи кроз одећу ослобађају сакралне нечистоте, као јунаци романа који су се након посете мосту одрекли фелеричне одеће, коју ће обући госпођица Анита и винути се у други свет, као и њен син, „слични Шагаловим летећим младенцима“. (Пешикан-Љуштановић 2016: 36) Највећи и најбољи проучавалац опуса Зорана

6 Исти аутор пише и о веровањима која су уврежена за самоубице, где је повратак у свет живих могућ јер је „довољно да се душа реинкарнира у некој жени и поново појави у виду детета“" (Ван Генеп 2005: 186), па тако и душе посетилаца јунака Мосй $а$ могу припадати људима који су раније шетали овим светом, али су у једном тренутку дигли руку на себе. 
Живковића, Љиљана Пешикан-Љуштановић истиче да је Анитин син заправо њен анимус, њена мушка половина са којом „досеже пуну целовитост и уживање у властитом духовном богатству“. (2016: 49)

Читање Мостиа далеко је инспиративније када се у разматрање дода још један Живковићев роман - Пей gунавских чуgа (објављен 2011. године), који броји пет необичних појава на пет европских мостова испод којих протиче „велики Дунав, река препуна чуда“. (Живковић 2011: 29) И овај роман испуњен је нестанцима, појављивањима, оживљавањима, персонификацијама, инспирацијама које се плаћају животом, буђењем савести, претварањем моста у роман овековечен у времену, јер рукописи не горе, па чак ни када се спале. Воајер који посматра бечки Жути мост рећи ће „као да се све чудачко и настрано у Бечу стицало на овом месту“. (Живковић 2011: 73) Плави мост у Новом Саду дела, мисли, говори, узноси се да би посетио остале мостове, кроз клизна врата на своју територију пропушта разне псе и упокојене људе и најзад оживљава са слике, „постаје мислећи ентитет који види и превазилази недостатке и мањкавости својих твораца“. (Пешикан-Љуштановић 2016: 70) Као и у Мостиy, скокови у воду нису праћени звуком ударања у водену површину, а јунаци који пониру са камених ограда, поново ће се вратити у причу, доказујући да скок није крај. Птичар, кроз чију визуру је исписана последња прича, критиковаће урођену људску склоност да се све објасни, склоност које човек никако не може да се ослободи, чак ни када би им он, пас, рекао „да је то што виде тек ситница“. (Живковић 2011: 29) ступајући у полемику са старешином Обласне управе за мостове: „Будимо трезвени. Свет је ипак разумно уређен. Или можда сматрате другачије?“. (Живковић 2011: 8) Дајући мосту централно место и читаву лепезу делатности и могућности 
које на необичан начин мењају ток живота многих људи, Живковић је овим романом подвукао важност мостова, не као „верних и ћутљивих“ творевина, како их је видео Андрић, већ као интерактивних грађевина које постају актери у људском животу, и то на најнезамисливије начине.

Роман Мосй Зорана Живковића може се читати на више различитих начина и сваки ће бити подједнако забаван и инспиративан за тумачење и дочитавање. Мајстор приповедања о различитим димензијама и стварностима, где су посете из прошлости и будућности итекако могуће, и у овом роману је показао јединствену ноту свог стваралаштва: његови јунаци, попут оних из бајке, неће стајати по страни, већ ће без питања пратити чудесно које ће се испречити на њиховом путу. Једно такво путешествије, особу ће из једне стварности пренети у другу, када се испуне сви услови за такву селидбу. Најзад, које би полазиште било прикладније од моста окруженог дрворедима кестенова ${ }^{7}$ ?

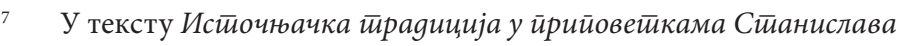

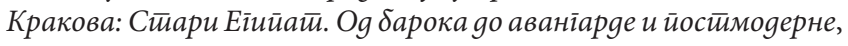
Јелена Марићевић пише о „виртуозно испраћеном мотиву кестења: 'Странац ... Његове очи имају боје мртвих кестенова ... ваљале се лубање као попадало кестење по земљи ... његове избуљене мртве очи биле су мрке као сва опала кестена'. (Краков 1992: 94, 99-100) Кестен очи постају сигнум за поглед у другу стварност (смрт) јер самим тим што се налазе на крају циклуса као плод који пада, сугеришу пролазност. [...] И код Данила Киша у Раним јаgима, кестен је ознака за пролазност, а у песми Кесшиен Васка Попе, кестен има својство да се измести и лута по паралелним стварностима: 'Живи од пустоловина/ својих недостижних корена/ и од дивних успомена/ на изненадне ноћи/ кад нестане из улице// Ко зна куда иде““. (Марићевић 2015: 104) Као, уосталом, и посетиоци који нестају са моста. 


\section{Извори и литература:}

Бидерман, Ханс. Речник симбола, превели са немачког Михаило Живановић, Хана Ћопић, Мерал Тарар-Тутуш. Београд: Плато, 2014.

Ван Генеп, Арнолд. Обреgи йрелаза, превела са француског Јелена Лома. Београд: Српска књижевна задруга. 2005.

Владушић, Слободан. „Мост између хуманизма и постхуманизма“. Кюижевности, бр. 2 (2007): 125-134.

Гарден, Нанон, и др. Мали Ларусов речник симбола, превели са француског Гордана Берберина и Бранко Ракић. Београд: Лагуна, 2011.

Гербран, Ален и Шевалије, Жан. Речник симбола: мийови, снови, обичаји, иоосииуйци, облици, тикови, боје, бројеви, превели са француског Павле Секеруш, Кристина Копрившек, Исидора Гордић. Нови Сад: Stylos art, 2009.

Живковић, Зоран. Мости. Београд: Лагуна, 2006.

Живковић, Зоран. Пет̄ gунавских чуgа. Београд: Завод за уџбенике, 2011.

Кулишић, Ж. и др. Срйски мийолошки речник. Београд: Нолит, 1970.

Марићевић, Јелена. „Источњачка традиција у приповеткама Станислава Кракова: Стари Египат. Од барока до авангарде и постмодерне“. Мирко Демић (ур.). Сйанислав Краков: аваніарgа, маріина, наслеђе. Зборник раяова о сииваралаштеву Сиианислава Кракова (1895-1968). Крагујевац: Народна библиотека Вук Караџић, 2015. 97-105.

Пешикан-Љуштановић, Љиљана. Зайочник ӥеиее силе. Фанйастичнна йроза Зорана Живковића. Нови Сад: Филозофски факултет, Бијело Поље: Радио Бијело Поље, 2016. 


\section{Marijana Jelisavčić \\ THE BRIDGE IN ZORAN ŽIVKOVIĆ'S NOVEL THE BRIDGE}

\section{Summary}

The bridge phenomenon in Zoran Živkovićs eponymous novel is viewed through a prism of unique events and encounters, which have brought the three main characters to the bridge, who emphasize the crux of the novel. Those encounters are not synchronized, but are connected to each other, and thus create an unclassifiable binding on the one hand, with the objects which gradually accumulate and on the other hand, with the bridge itself, which in the vortex of impossible stories, appears to represent the locus delicti. The bridge is temporarily developing into a warehouse for the objects, which the heroes leave behind them before they cross the bridges and reach for the water area, which should be not interpreted as a potential death, but more as a continuation of the day, which will not appear as quite peculiar, like the miracle that has led the main figures to the threshold of the bridge.

Key words: bridge, coat, escharpe, shoes. 